\title{
IMPLEMENTASI ICE BREAKING PADA MATA KULIAH MATEMATIKA 3 DI PROGRAM STUDI PENDIDIKAN MATEMATIKA STKIP SYEKH MANSHUR
}

\section{THE IMPLEMENTATION OF ICE BREAKING ON MATHEMATICS 3 SUBJECT AT MATHEMATICS EDUCATION STUDY PROGRAM OF STKIP SYEKH MANSHUR}

\author{
LINDA \\ Sekolah Tinggi Keguruan dan IImu Pendidikan Syekh Manshur \\ Jalan Raya Labuan KM. 5 Kadulisung Pandeglang \\ Posel: 082111932159 \\ Surel: linda90linda@gmail.com
}

\begin{abstract}
Abstrak
Penelitian ini bertujuan untuk mendeskripsikan implementasi ice breaking pada mata kuliah Matematika 3 di Program Studi Pendidikan Matematika STKIP Syekh Manshur. Penelitian ini merupakan penelitian kualitatif. Subjek penelitian sebanyak 7 mahasiswa yang dipilih secara purposive sampling dari 23 mahasiswa program studi pendidikan matematika STKIP Syekh Manshur tahun akademik 2018/2019. Data hasil penelitian dianalisis dari hasil observasi, wawancara, dan dokumentasi. Hasil penelitian menunjukkan bahwa implementasi ice breaking pada mata kuliah Matematika 3 dapat dijadikan sebagai salah satu alternatif untuk menghilangkan rasa bosan, mengembalikan perhatian/konsentrasi, memberikan rasa senang, semangat, ceria, dan mendukung kondusifitas perkuliahan di kelas. Hasil ini juga sejalan dengan peningkatan hasil perkuliahan yang berada pada nilai rerata baik, yaitu sekitar $70-89$.
\end{abstract}

Kata Kunci: ice breaking, mata kuliah Matematika 3

\begin{abstract}
This study aims to describe the implementation of ice breaking on Mathematics 3 subject at Mathematics Education Study Program of STKIP Syekh Manshur. This research is qualitative research. Research's subjects are seven students who were selected by purposive sampling from 23 students of the Mathematics Education Study Program of STKIP Syekh Manshur academic year 2018/2019. The research data are analyzed from observations, interviews, and documentation. The results shows that the implementation of ice breaking can be used as an alternative to eliminate boredom, restore attention/concentration, give a sense of fun, enthusiasm, cheerful, and support the conduciveness of lectures in the classroom. These also give positive impact to the students' scores, which mainly state at 70-89.
\end{abstract}

Keywords: ice breaking, the subject of Mathematics 3 


\section{PENDAHULUAN}

Seseorang yang sedang belajar di perguruan tinggi disebut sebagai mahasiswa. Hal ini sesuai dengan pengertian dari Siswoyo (2007: 121) mahasiswa yaitu individu yang sedang menuntut ilmu ditingkat perguruan tinggi, baik mereka yang belajar di perguruan tinggi negeri maupun swasta atau lembaga lain yang setingkat dengan perguruan tinggi. Mahasiswa dapat diibaratkan seperti dari remaja kedewasa dan dari senior di Sekolah Menengah Atas menjadi pelajar (mahasiswa) di perguruan tinggi (Melly, 2008: 1). Pada tingkat perguruan tinggi, pembelajarannya tentu saja berbeda dengan di sekolah. Disekolah pengajar disebut dengan guru sedangkan di perguruan tinggi pengajar disebut dosen. Sesuai dengan pendapat Gunarsa (2000) pola hubungan dosen dengan mahasiswa sangat berbeda dengan hubungan guru dengan siswa. Perhatian dosen ke mahasiswa lebih sedikit dibandingkan dengan guru ke siswanya.

Pada tingkat perguruan tinggi anak sudah dianggap dewasa serta dapat belajar mandiri. Mahasiswa dianggap sebagai anak didik yang dewasa tanpa perlu diperlakukan seperti anak-anak, sehingga dalam proses pembelajaran diperkuliahan mahasiswa dituntut mandiri, dewasa, tanggungjawab dan serius. Namun, terkadang mahasiswa juga manusia biasa yang tidak harus melulu serius melakukan kegiatan pembelajaran pada perkuliahan. Bahkan dari hasil obrolan peneliti dengan mahasiswa mereka seperti ingin kembali ke masamasa SMA, SMP, dan SD yang penuh tawa lepas tidak banyak beban pikiran dalam belajar di kelas.

Mata kuliah di program studi pendidikan matematika STKIP Syekh Manshur pada semester genap yaitu semester IV tahun akademik 2018/2019 terdapat mata kuliah Matematika 3 (2 SKS). Mata kuliah Matematika 3 yaitu mata kuliah wajib yang harus diambil oleh Mahasiswa Program Studi Pendidikan matematika STKIP Syekh Manshur, dan memiliki mata kuliah prasyarat. Mahasiswa yang akan mengambil mata kuliah Matematika 3 terlebih dahulu harus lulus mata kuliah matematika 1 dan 2. Pada mata kuliah matematika 3 , mahasiswa mempelajari materi system persamaan linier dua variabel (SPLDV) dan aritmatika sosial.

Pada semester genap ini, jadwal mata kuliah matematika 3 yaitu Jumat pukul 13.00 WIB s.d. 15.00 WIB. Pada jam tersebut merupakan jam-jam kritis 
dengan konsentrasi mahasiswa tidak $100 \%$ mengikuti mata kuliah. Sebagai dosen yang mengampu mata kuliah tersebut, tentunya memikirkan cara/strategi yang tepat agar mahasiswa pada saat jam tersebut dapat mengikuti perkuliahan di kelas dengan baik, fokus, antusias dan bahagia. Dikarenakan pembelajaran di perguruan tinggi rerata perkuliahan di dalam kelas selalu serius, menegangkan, tertekan, dan membosankan. Sehingga mahasiswa mengalami stres, ketakutan, motivasinya kurang, dan tidak tertarik dengan perkuliahan yang diambilnya. Salah satu cara yang dapat mengurangi hal-hal perasaan dan pikiran negatif mahasiswa dalam perkuliahan Matematika 3 yaitu dengan mengimplementasikan ice breaking pada proses perkuliahan di kelas.

\section{KAJIAN TEORETIK}

Menurut Soenarno (Caswita 2005: 1) Ice breaking merupakan peralihan situasi dari yang membosankan, membuat ngantuk, menjenuhkan, dan tegang menjadi rileks, bersemangat, tidak membuat mengantuk, serta ada perhatian dan ada rasa senang untuk mendengarkan atau melihat orang lain yang berbicara di depan kelas atau ruangan pertemuan. Adapun menurut Sunarto, (2012: 1) ice breaking dalam pembelajaran dapat diartikan sebagai pemecah situasi kebekuan pikiran atau fisik siswa. Ice breaking digunakan untuk menciptakan suasana belajar dari pasif menjadi aktif dari kaku menjadi gerak, akrab dan dari jenuh menjadi riang.

Jadi ice breaking merupakan suatu kegiatan memecah kebekuan untuk mengubah suasana hati dan pola pikir negatif menjadi suasana hati yang positif, menyenangkan dan semangat. Kegiatan ini biasanya berupa suatu kelucuan, games, memberikan informasi, cerita lucu, dan ada kalanya pencerahan (sharing pengalaman yang menginspirasi). Ice breaking bisa menjadi cara yang tepat untuk memfasilitasi kesuksesan suatu acara/kegiatan termasuk dalam proses pembelajaran/perkuliahan. Dengan demikian, tujuan pada penelitian ini adalah mendeskripsikan implementasi ice breaking pada mata kuliah matematika 3 program studi pendidikan matematika semester IV STKIP Syekh Manshur.

\section{METODE PENELITIAN}

Penelitian ini merupakan penelitain kualitatif. Data yang dideskripsikan adalah implementasi ice 
breaking pada perkuliahan Matematika 3 di Program Studi Pendidikan Matematika Semester IV STKIP Syekh Manshur tahun akademik 2018/2019. Tempat penelitian dilaksanakan di Program Studi Pendidikan Matematika STKIP Syekh Manshur. Waktu pelaksanaan penelitian yaitu selama perkuliahan di semester genap tahun akademik 2018/2019.

Subjek penelitian adalah tujuh mahasiswa pendidikan matematika semester IV yang dipilih secara purposive sampling. Ketujuh mahasiswa tersebut dalam perkuliah Matematika 3 diberikan ice breaking kurang lebih 15 menit. Selama perkuliah satu semester tersebut peneliti mengambil data melalui observasi langsung, wawancara, dan dokumen dari hasil nilai rerata (berdasarkan nilai kehadiran, tugas, UTS dan UAS).

Observasi dilihat dari setiap perkuliahan di kelas, subjek diberikan ice breaking mulai dari perilaku mahasiswa, perasaan hati mereka, dan respon mereka dalam perkuliah matematika 3. Wawancara setelah melakukan perkuliahan selama satu semester. Peneliti melakukan wawancara langsung maupu tertulis, terkait dengan tanggapan mereka ketika mengikuti perkuliahan matematika 3 dengan menggunakan ice breaking setiap pertemuan dari pertemuan awal sampai dengan akhir perkuliahan semester genap tahun akademik 2018/2019. Dokumen dilihat dari hasil nilai rata-rata (berdasarkan nilai kehadiran, tugas, UTS dan UAS). Peneliti memulai mengambil data pada tanggal 23 Maret s.d. 5 Juli 2019 dari pertemuan ke-1 perkuliahan sampai dengan pertemuan ke-16.

\section{HASIL DAN PEMBAHASAN}

Hasil observasi peneliti selama satu semester menunjukkan bahwa implementasi ice breaking pada mata kuliah Matematika 3 berdampak pada suasana perkuliahan di kelas yang lebih menyenangkan, rileks, dan mahasiswa semangat mengikuti perkuliahan dari awal sampai akhir. Mereka tidak merasa bosan walau jadwal mata kuliah terserbut berada di jam 13.00 WIB - 15.00 WIB.

Hasil wawancara menunjukkan bahwa perkuliahan Matematika 3 dengan mengimplementasikan ice breaking sangat menyenangkan, asik sehingga materi mudah dipahami, perkuliahan tidak monoton, menarik, membuat suasana perkuliahan di kelas hidup, dan bahkan terdapat mahasiswa meminta untuk perbanyak permainan. Namun, terdapat juga 
mahasiswa yang tidak menyenangi cara perkuliahan dengan menggunakan ice breaking. Walaupun perkuliahan di kelas mengimplementasikan ice breaking, peneliti tetap memberikan tugas (setiap pertemuan diberikan tugas), memberikan soal ketika di kelas untuk dikerjakan oleh mahasiswa, Sehingga dari tujuh mahasiswa yang menjadi subjek, satu subjek menyatakan mengajar jangan terlalu serius, jangan terlalu banyak memberikan soal, dan jangan terlalu banyak memberikan tugas.

Hasil dokumen yang diambil dari hasil kehadira, tugas, UTS, dan UAS, dapat dilihat pada tabel dibawah ini.

Tabel 1. Hasil Nilai Akhir Mahasiswa

\begin{tabular}{c|c|c|c|c|c}
\hline \multirow{2}{*}{ Subjek } & \multicolumn{4}{|c|}{ Nilai } & \multirow{2}{*}{ Rerata } \\
\cline { 2 - 5 } & \multirow{2}{*}{ K } & T & UTS & UAS & \\
\hline M1 & 85 & 86 & 80 & 73 & 81 \\
\hline M2 & 85 & 86 & 65 & 50 & 72 \\
\hline M3 & 90 & 86 & 80 & 75 & 83 \\
\hline M4 & 90 & 86 & 90 & 85 & 88 \\
\hline M5 & 85 & 86 & 50 & 65 & 72 \\
\hline M6 & 90 & 86 & 70 & 80 & 82 \\
\hline M7 & 80 & 63 & 80 & 60 & 71 \\
\hline
\end{tabular}

Ice breaking bermanfaat sekali pada situasi perkuliahan di kelas mata kuliah matematika. Walau subjek peneliti adalah mahasiswa yang dapat diatur dan sudah dewasa dengan pola pikir yang matang, serta mereka sudah memililiki rasa tanggungjawab. Tetapi tetap saja mereka adalah manusia biasa yang memiliki rasa bosan, jenuh, kurang konsentrasi dalam proses pembelajaran di kelas.

Dengan mengimplementasikan ice breaking, dari hasil observasi peneliti selama satu semester menunjukkan bahwa rata-rata subjek menyatakan perkuliahan Matematika 3 menyenangkan dan tidak membosanka. Hal ini dikarenakan pada saat perkuliahan mereka selalu diberikan permainan yang bervariasi sehingga merasa senang, enjoy mengikuti perkuliahan bahkan mereka menjadi bersemangat untuk terus hadir pada perkuliahan matematika 3 .

Suasana perkuliahan hidup, dan penuh dengan tawa. Ice breaking yang digunakan oleh peneliti setiap pertemuan berbeda-beda. Ada yang menggunakan permainan tebak nama, tebak gambar, tebak gaya, permainan identitas diri, cerita lucu, cerita inspirasi, dan lain sebagainya. Ice breaking diberikan secara kondisional, dilihat dari kondisi jenuh/bosannya subjek dalam perkuliahan matematika 3, jadi ice breaking bisa di awal perkuliahan, pertengahan, dan akhir perkuliahan. Dari ketiga waktu tersebut apabila sudah terlihat tanda-tanda 
mahasiswa bosan maka peneliti melakukan ice breaking. Waktu untuk ice breaking di kelas perkuliahan sekitar 15 menit.

Hasil observasi peneliti yang sudah dipaparkan tadi dapat diperkuat lagi dari hasil wawancara subjek penelitian. Mereka merasa perkuliahan dengan mengimplementasikan ice breaking baik sekali dan sangat bermanfaat. Manfaat yang dirasakan adalah perkuliahan sangat menyenangkan, asik sehingga materi mudah dipahami, perkuliahan tidak monoton, menarik, membuat suasana perkuliahan di kelas hidup, semakin dekat dengan teman, menghilangkan stres/kebosanan/kejenuhan dalam perkuliahan di kelas. Manfaat ice breaking dapat menghilangkan kebosanan, kejemuan, kecemasan, dan keletihan karena bisa keluar sementara dari rutinitas pelajaran dengan melakukan aktivitas gerak bebas dan ceria, melatih berpikir secara kreatif, melatih berinteraksi dalam kelompok, meningkatkan rasa percaya diri, melatih konsentrasi, berani bertindak dan tidak takut salah, merekatkan hubungan interpersonal, melatih untuk menghargai orang lain, memantapkan konsep diri, melatih jiwa kepemimpinan, dan melatih mengambil keputusan dan tindakan.
Adapun subjek yang menyatakan tidak baik itu faktor subjektif, terdapat mahasiswa tidak suka dengan mata kuliah matematika 3, motivasi belajar kurang, dan tidak suka dengan aturan perkuliahan selama satu semester contoh diberikan tugas dan soal-soal latihan. Dari tujuh mahasiswa yang menjadi subjek hanya satu subjek yang tidak menyenangi mata kuliah Matematika 3 walau sudah menggunakan ice breaking pada mata kuliah tersebut. Dapat dibuktikan dari hasil wawancaran, subjek M7 menyatakan "mata kuliah matematika terlalu banyak tugas, selalu mengerjakan soal, tidak ada remedial apabila nilai kecil, dan terlalu serius".

Hasil dokumentasi menunjukan dari nilai kehadiran tugas, UTS, dan UAS. Rerata nilai akhir berada di B. Ada satu subjek yang mendapatkan nilai rata-rata $A$. dapat disimpulkan hasil nilai perkuliahan matematika 3 dengan mengimpelementasikan ice breaking yaitu baik, tidak terdapat nilai C. Hal ini dikarenakan banyak faktor. (1) kemampuan subjek, dari 7 subjek 6 subjek mendapat nilai B dan 1 subjek mendapat nilai A. Subjek yang mendapat nilai $B$, kemampuan mereka Rerata hasil ujian UTS dan UAS menperoleh nilai berada di 70 - 84 . kehadiran dari 6 subjek, 5 subjek (M1, 
M2, M3, M5, M6) 85\% mereka hadir, tugas maksimal, dan nilai UTS, UAS baik. Namun terdapat 1 subjek hanya $80 \%$ mengikuti perkuliahan ditambah menyelesaikan tugas kurang maksimal dan hasil UTS 80, dan UAS 60. Untuk 1 subjek (M4) yang mendapatkan nilai rata-rata $A$ yaitu 88 , subjek tersebut dari kehadiran, tugas, UTS, dan UAS semua hasilnya baik. Nilai UTS dan UAS pada subjek M4 90 dan 85. Dengan demikian, data dokumen yang dilihat dari hasil nilai rerata (kehadiran, tugas, UTS dan UAS) mata kuliah Matematika 3 adalah baik.

\section{SIMPULAN}

Berdasarkan hasil penelitian dan pembahasan dapat disimpulkan bahwa implementasi ice breaking pada mata kuliah Matematika 3 Program Studi Pendidikan Matematika Semester IV STKIP Syekh Manshur dapat dijadikan sebagai salah satu alternatif untuk menghilangkan rasa bosan, mengembalikan perhatian/konsentrasi, meberikan rasa senang, semangat, ceria, dan mendukung kondusifitas perkuliahan di kelas. Dari hal-hal positif yang dirasakan oleh subjek memberikan dampak positif pula pada hasil perkuliahan. Terbukti dari hasil perkuliahan pada mata kuliah matematika 3 nilai mahasiswa sebagai subjek peneliti berada di rata-rata baik (nilai berkisar 70 - 89). Berdasarkan hasil penelitian, pembahasan, dan simpulan, dosen pada program studi pendidikan matematika STKIP Syekh Manshur harus kreatif, dan berani berinovasi ketika proses perkuliahan di kelas. Salah satunya dengan mengimplementasikan ice breaking kepada mahasiswa pada saat perkuliah di kelas. Bagi peneliti lain yang tertarik untuk melaksanakan implementasi ice breaking dalam perkuliahan dapat menambahkan subfokus yang lain agar hasil penelitian menjadi lebih mendalam.

\section{DAFTAR PUSTAKA}

Caswita. (et all). Pengaruh Pembelajaran Inkuiri Dengan Selingan (Ice Breaker) Terhadap Pemahaman Konsep Matematis. Jurnal Pendidikan Matematika. Volume 1, Nomor 4, November. 2012. (Universitas Lampung diakses pada tanggal 5 Juni 2019).

Gunarsa, S. D, \& Gunarsa, Y. S. D. Psikologi Perkembangan Anak dan Remaja. Jakarta: BPK Gunung Mulia, 2000.

Melly. Hubungan Antara Kreativitas dan Stres Pada Mahasiswa Tahun Pertama Jurusan Arsitektur 
Universitas Indonesia. Depok:

Skripsi FPSI UI, 2008. (Diakses

pada tanggal 5 juni 2019).

Siswoyo, Dwi. Ilmu Pendidikan.

Yogyakarta: UNY Press, 2007.

Sunarto. Ice Breaker dalam

Pembelajaran Aktif. Surakarta:

Cakrawala Media, 2012. 